\title{
Six cases of citrin deficiency in Korea
}

\author{
JUNG MIN KO ${ }^{1}$, GU-HWAN KIM ${ }^{2}$, JU-HYUN KIM ${ }^{2}$, JAE YOUNG KIM ${ }^{3}$, JIN-HO CHOI ${ }^{3}$, \\ MIHARU USHIKAI ${ }^{4}$, TAKEYORI SAHEKI ${ }^{4}$, KEIKO KOBAYASHI ${ }^{4}$ and HAN-WOOK YOO ${ }^{1,2}$ \\ ${ }^{1}$ Department of Pediatrics, ${ }^{2}$ Medical Genetics Clinic and Laboratory, Asan Medical Center, \\ University of Ulsan College of Medicine, Seoul; ${ }^{3}$ Department of Pediatrics, Chungnam National University \\ College of Medicine, Daejeon, Korea; ${ }^{4}$ Department of Molecular Metabolism and Biochemical Genetics, \\ Kagoshima University Graduate School of Medical and Dental Sciences, Kagoshima, Japan
}

Received August 10,2007; Accepted September 28, 2007

\begin{abstract}
Citrin deficiency resulting from mutations of the SLC25A13 gene is associated with two major clinical phenotypes; neonatal intrahepatic cholestasis caused by citrin deficiency (NICCD) and adult-onset type 2 citrullinemia (CTLN2). In Korea, 6 cases of citrin deficiency were diagnosed based on biochemical and molecular findings. Four NICCD patients ( 2 boys and 2 girls) presented high citrulline levels on a newborn screening test or neonatal cholestasis. They were associated with conjugated hyperbilirubinemia, elevated liver enzymes, hypoalbuminemia, mild hyperammonemia, elevated citrulline, methionine and threonine. All of the hepatic manifestations were resolved spontaneously at the age of 5-9 months. Mutation analysis identified them as compound heterozygotes carrying each of the c.851del4, IVS $11+1 \mathrm{G}>\mathrm{A}, \mathrm{IVS} 13+1 \mathrm{G}>\mathrm{A}, \mathrm{G} 393 \mathrm{~S}$, and IVS $16 \mathrm{ins} 3 \mathrm{~kb}$ mutant alleles. Two adult male CTLN2 patients were identified. They were aged 24 and 37 years, and presented sudden loss of consciousness, hyperammonemia and citrullinemia. They were compound heterozygotes with IVS13+1G $>$ A and IVS16ins $3 \mathrm{~kb}$, and with c.851del4 and IVS $11+1 \mathrm{G}>\mathrm{A}$ mutant alleles. This report describes the clinical characteristics, biochemical findings and molecular analysis of the SLC25A13 gene of patients with citrin deficiency in Korea.
\end{abstract}

\section{Introduction}

Adult-onset type 2 citrullinemia (CTLN2) is characterized by episodes of neurological symptoms associated with hyper-

Correspondence to: Dr Han-Wook Yoo, Department of Pediatrics, Asan Medical Center, University of Ulsan College of Medicine, 388-1 Pungnap-2dong, Songpa-gu, Seoul 138-736, Korea

E-mail: hwyoo@amc.seoul.kr

Abbreviations: CTLN2, adult-onset type 2 citrullinemia; ASS, argininosuccinic acid synthetase; AGC, aspartate-glutamate carrier; NICCD, neonatal intrahepatic cholestasis caused by citrin deficiency; $\mathrm{PCR}$, polymerase chain reaction

Key words: citrin deficiency, adult-onset type 2 citrullinemia, neonatal intrahepatic cholestasis, SLC25A13 ammonemia leading to disorientation, irritability, seizures and coma. The serum citrulline level is elevated while the activity of argininosuccinic acid synthetase (ASS) in liver tissue is decreased. CTLN2 is distinct from classical citrullinemia caused by a mutation of the ASS gene. In 1999, Kobayashi et al identified the novel SLC25A13 gene on chromosome 7q21.3, and showed that five distinct mutations occurred in CTLN2 patients (1). Citrin, encoded by $S L C 25 A 13$, is a liver-type mitochondrial aspartate-glutamate carrier (AGC). The deficiency in citrin causes not only CTLN2, in autosomal recessive trait, but also neonatal intrahepatic cholestasis with multiple aminoacidemia and galactosemia. This condition is named neonatal intrahepatic cholestasis caused by citrin deficiency (NICCD) $(2,3)$.

It was previously thought that CTLN2 and NICCD occurred almost exclusively in Japan. Recently, however, several cases have been found in other Asian patients including those of Ashkenazi Jewish, Chinese, Israeli, Palestinian, Taiwanese and Vietnamese origin (4-6). Citrin deficiency is relatively common, especially in Japanese individuals, where the frequency of the SLC25A13 mutant allele is approximately 1 in 70 (7).

In this study, we analyzed clinical characteristics and genotypes of the SLC25A13 gene in Korean patients with NICCD and CTLN2.

\section{Materials and methods}

Patients. Four NICCD (two boys and two girls) and two male CTLN2 patients were investigated in this study. Diagnosis of citrin deficiency was based on the clinical characteristics, biochemical findings and mutation analyses. Gene analysis was performed in all six patients. The following clinical and biochemical data were obtained by a retrospective medical chart review: sex, age at diagnosis, symptoms and signs, serum amino acid profiles, ammonia levels in the blood, serum galactose levels, liver transaminase levels in the blood, serum protein and albumin levels.

Mutation analysis and DNA diagnosis of the SLC25A13 gene. Genomic DNA was isolated from peripheral blood leukocytes using a Puregene DNA Isolation Kit (Gentra Systems, MN). Eighteen exons of the SLC25A13 gene and their intronic 
flanking sequence were amplified by polymerase chain reaction (PCR) with 18 sets of primers. Amplification was performed in 30 cycles; each cycle consisted of denaturation at $95^{\circ} \mathrm{C}$ for $30 \mathrm{sec}$, annealing at $55^{\circ} \mathrm{C}$ for $30 \mathrm{sec}$, and extension at $72^{\circ} \mathrm{C}$ for $45 \mathrm{sec}$. The PCR reactions were carried out in reaction volumes of $20 \mu \mathrm{l}$, containing $100 \mathrm{ng}$ of genomic DNA template; the reactions were $1 \mu \mathrm{M}$ each primer, $200 \mu \mathrm{M}$ in each dNTPs, $1.5 \mathrm{mM}$ in $\mathrm{MgCl}_{2}, 50 \mathrm{mM}$ in $\mathrm{KCl}, 10 \mathrm{mM}$ in Tris- $\mathrm{HCl}(\mathrm{pH} 8.3)$. The reactions contained $0.2 \mu \mathrm{l}$ of Taq polymerase (Promega, Madison, WI). After amplification, PCR mixtures were electrophoresed on $1.2 \%$ agarose gel in the presence of ethidium bromide to verify the size and purity of the PCR products.

After verifying that unique PCR products were amplified, DNA sequencing was performed using the same primers used for PCR, and the BigDye Terminator v3.0 Cycle Sequencing Ready Reaction Kit (Applied Biosystems, Foster City, CA) according to the manufacturer's instructions. The amplification protocol consisted of 30 cycles at $94^{\circ} \mathrm{C}$ for $20 \mathrm{sec}$, at $55^{\circ} \mathrm{C}$ for $20 \mathrm{sec}$ and at $72^{\circ} \mathrm{C}$ for $30 \mathrm{sec}$ with a PTC-200 PCR machine (MJ Research, Watertown, MA). In each reaction, we used 10 ng of PCR product, treated with exonuclease I and shrimp alkaline phosphatase (Amersham Pharmacia Biotech, Piscataway, NJ), as a template, and $10 \mathrm{pM}$ of primer was added. Incorporated dyes were removed by ethanol precipitation. An ABI PRISM 3100 Genetic analyzer (Applied Biosystems) was used to derive the DNA sequence. To rule out classical citrullinemia, the ASS gene was analyzed in all patients by a direct sequencing method after PCR amplifications as described above.

Diagnoses of known mutations were also confirmed by GeneScan and the Snapshot methods (3). Detailed methods for identification and diagnosis of a novel mutation, [XIX]:IVS16ins3kb, will be described elsewhere (Tabata et al unpublished data). Clinical and biochemical data have been reported previously in Japanese (8) and Korean (9) NICCD patients with the $[\mathrm{XIX}]$ mutation.

\section{Results}

Clinical characteristics and genotypes of NICCD. Patient 1 was brought to the outpatient clinic at the age of 39 days because of a high serum citrulline level of $331 \mu \mathrm{mol} / 1$ (normal range 3-35 $\mu \mathrm{mol} / \mathrm{l}$ ) indicated by a neonatal mass screening test. Birth weight was $2.8 \mathrm{~kg}$ and the boy was being fed breast milk. He had mild jaundice (total bilirubin $7.3 \mathrm{mg} / \mathrm{dl}$ ), but hepatomegaly was absent. Laboratory findings showed a serum methionine level of $29.2 \mu \mathrm{mol} / 1$ (normal range 10-60 $\mu \mathrm{mol} / \mathrm{l}$ ), a threonine level of $547 \mu \mathrm{mol} / 1$ (normal range $24-174 \mu \mathrm{mol} / \mathrm{l}$ ), a galactose level of $32.5 \mathrm{mg} / \mathrm{dl}$ (normal range $0-20 \mathrm{mg} / \mathrm{dl}$ ), an ammonia level of $285 \mu \mathrm{mol} / 1$ (normal range 10-35 $\mu \mathrm{mol} / \mathrm{l}$ ), an alkaline phosphatase level of 757 IU/l (normal range 145$420 \mathrm{IU} / \mathrm{l})$ and an aspartate aminotransferase level of $87 \mathrm{IU} / 1$ (normal range 15-55 IU/l). Urine organic acid analysis revealed no prominent abnormalities. Molecular analysis of the $S L C 25 A 13$ gene revealed that the boy was a compound heterozygote with c. $1177+1 \mathrm{G}>\mathrm{A}(\mathrm{IVS} 11+1 \mathrm{G}>\mathrm{A})$ and IVS16ins $3 \mathrm{~kb}$. He was treated with sodium benzoate and L-arginine. All clinical and abnormal laboratory findings were resolved by 5 months of age (Figs. $1 \mathrm{~A}$ and $2 \mathrm{~A}$ ). The
(A)

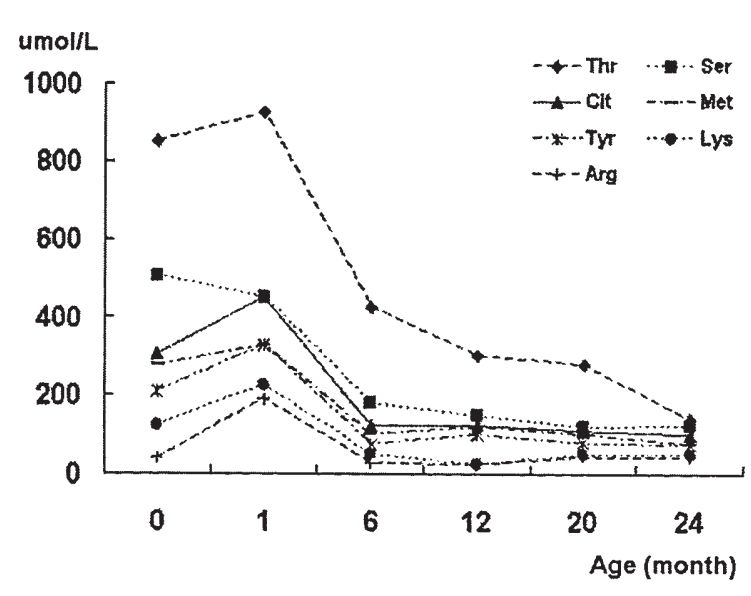

(B)

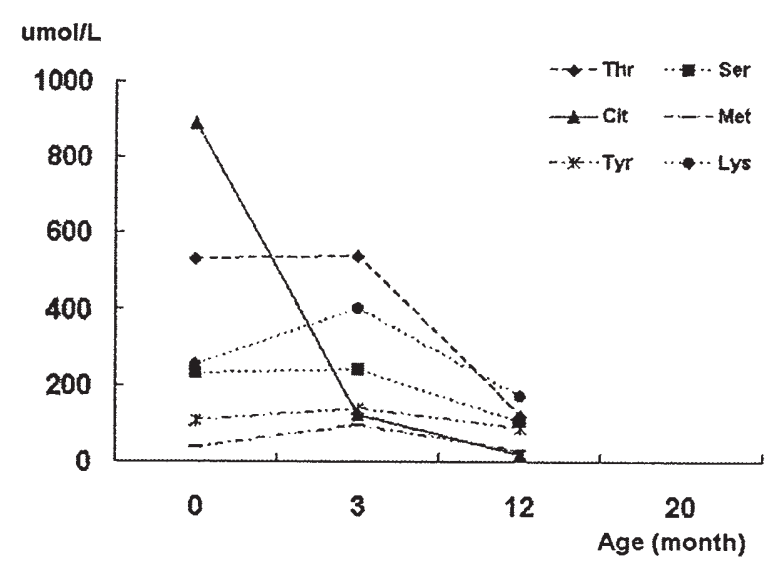

(C)

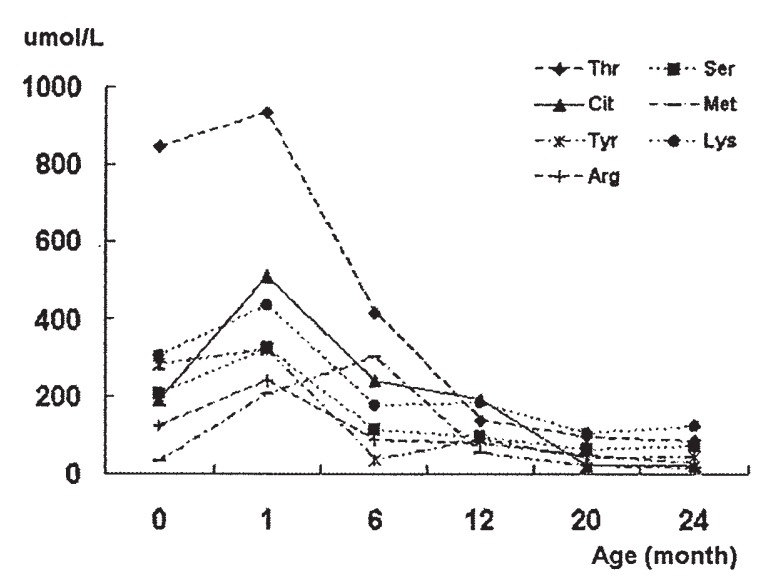

Figure 1. Sequential change of serum amino acid profiles in patient 1 (A), patient 2 (B) and patient 3 (C).

boy is now aged 20 months and developing normally with a preference for soy milk.

Patient 2 was brought to our hospital at the age of 30 days because of a high serum citrulline level $(888 \mu \mathrm{mol} / \mathrm{l})$ on a neonatal mass screening test. She was born by normal vaginal delivery with body weight of $2.36 \mathrm{~kg}$ and was being fed breast milk. Jaundice (total bilirubin $9.8 \mathrm{mg} / \mathrm{dl}$ ) and mild hepatomegaly were detected by physical examination. Laboratory findings showed a direct bilirubin level of $2.4 \mathrm{mg} / \mathrm{dl}$ (normal 
(A)

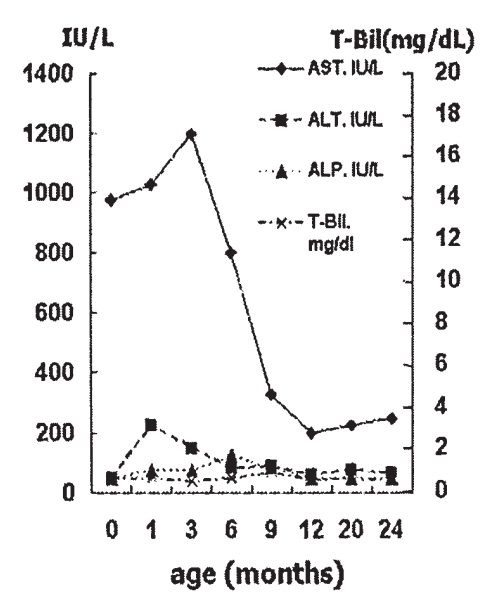

(B)

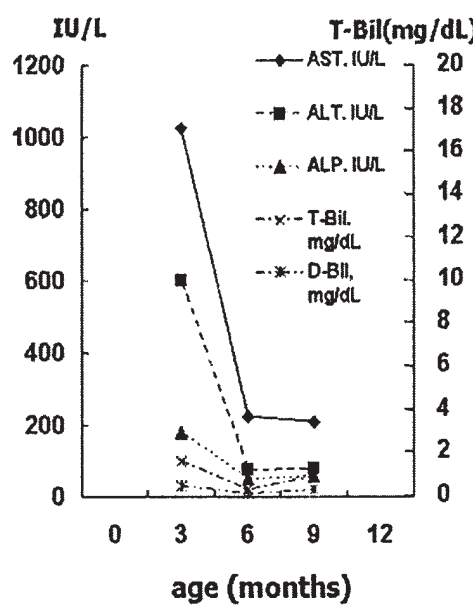

(C)

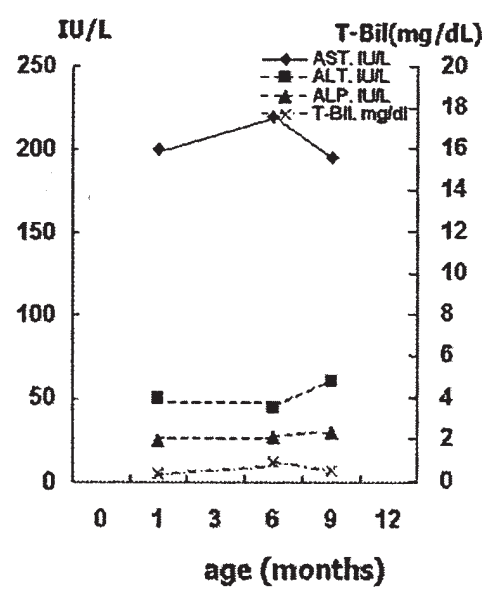

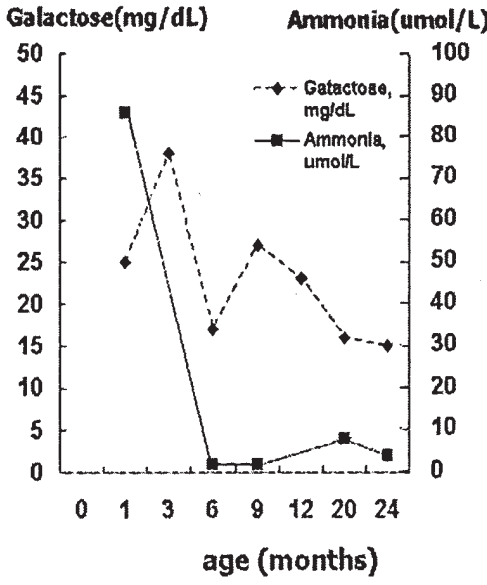
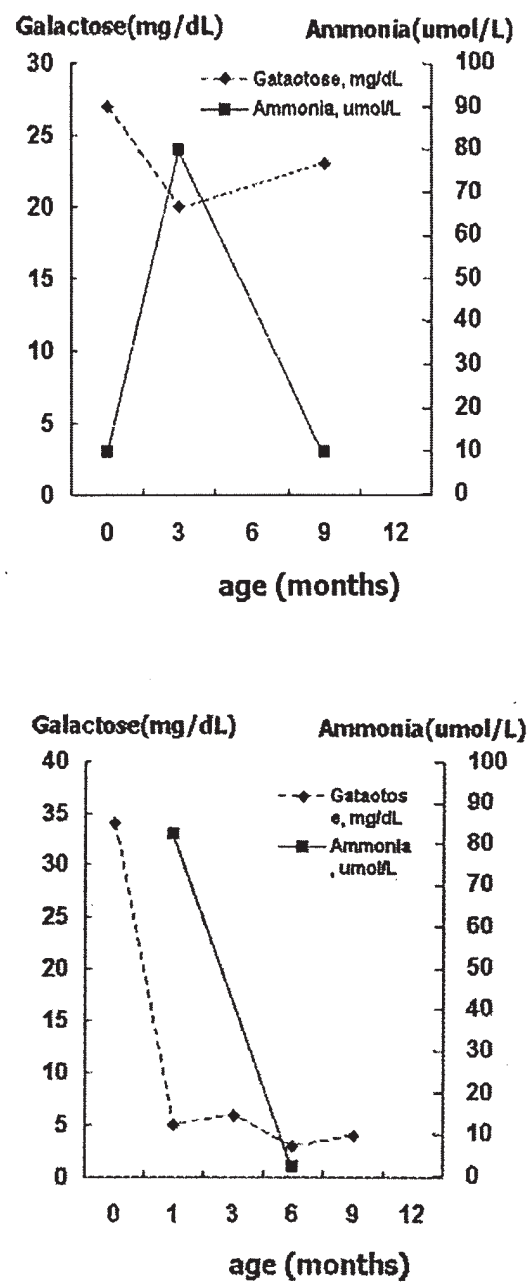

Figure 2. Sequential change in liver function, plasma galactose and ammonia in patient 1 (A), patient 2 (B) and patient 3 (C).

range $<0.2 \mathrm{mg} / \mathrm{dl}$ ) and a serum albumin level of $2.2 \mathrm{~g} / \mathrm{dl}$ (normal range 3.9-5.0 g/dl). Serum methionine (94.5 $\mu \mathrm{mol} / \mathrm{l}$ ), threonine $(534.6 \mu \mathrm{mol} / \mathrm{l})$, galactose $(24.3 \mathrm{mg} / \mathrm{dl})$, ammonia (201 $\mu \mathrm{mol} / \mathrm{l})$ and alkaline phosphatase (1044 IU/l) levels were elevated at the time of diagnosis c c. $1230+1 \mathrm{G}>\mathrm{A}$ (IVS13+1G >A) and IVS16ins3kb mutations in the SLC25A13 gene were identified by molecular analysis. Treatment with sodium benzoate and L-arginine was attempted. All clinical and abnormal laboratory findings were resolved at the age of 9 months. The girl is now 20 months of age and developing normally with a preference for egg and ham (Figs. 1B and 2B).

Patient 3 was brought to the hospital at the age of 37 days. The presenting symptoms were intermittent vomiting and a high citrulline level $(189 \mu \mathrm{mol} / \mathrm{l})$ on a neonatal mass 

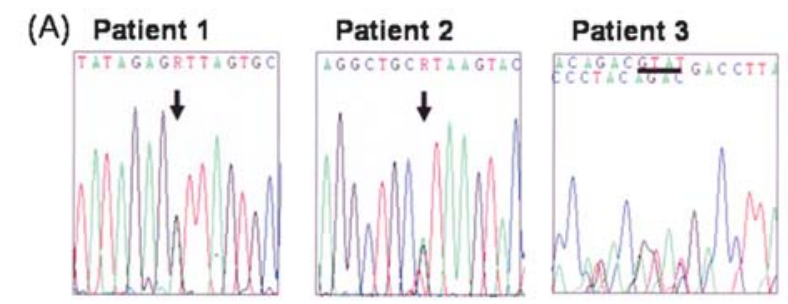

(B) Patient 5 Patient 6

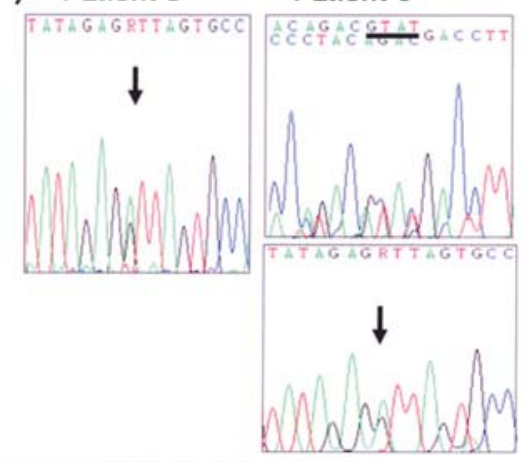

Patient 4

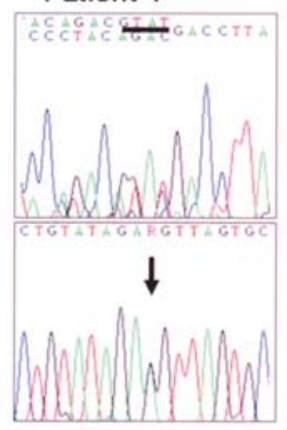

(C)

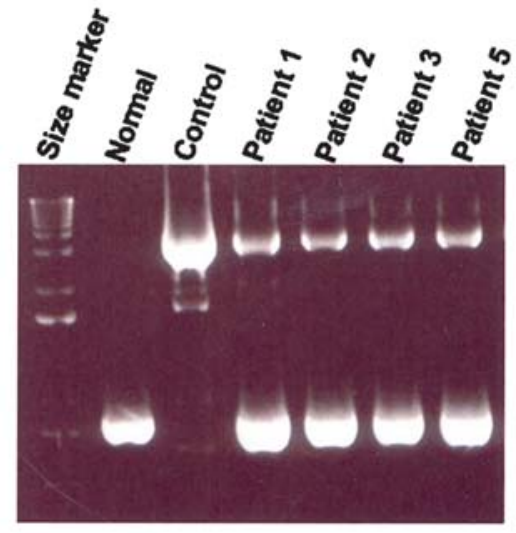

Figure 3. The mutation sequences of SLC25A13 for patients with (A) NICCD and (B) CTLN2, were performed in the ABI PRISM 3100 Genetic Analyzer with BigDye v3.0. The ' $R$ ' means a heterozygosity of nucleotide ' $A$ ' and ' $G$ '. To identify the IVS16ins3kb mutation, PCR analysis was carried out using the primer set spanning exon 16-17. PCR products were electrophoresed on $1.2 \%$ agarose gel (C). Approximately $3.5 \mathrm{~kb}$ of insertion mutation allele were revealed with 881 bp normal allele.

screening test. Mild jaundice (total bilirubin $8.1 \mathrm{mg} / \mathrm{dl}$ ) and mild hepatomegaly (3 finger breadths below the right costal margin) were detected by physical examination. Serum threonine $(844.1 \mu \mathrm{mol} / \mathrm{l})$, tyrosine $(282.8 \mu \mathrm{mol} / \mathrm{l}$; normal range $22-108 \mu \mathrm{mol} / \mathrm{l})$, galactose $(42.6 \mathrm{mg} / \mathrm{dl})$ and ammonia (129 $\mu \mathrm{mol} / \mathrm{l})$ levels were elevated at diagnosis. Serum alkaline phosphatase level (1251 IU/1) and $\gamma$-glutamyl transferase (141 IU/1; normal range 12-123 IU/l) levels were elevated. The boy was shown to be a compound heterozygote with c.851_854del (c.851del4) and IVS16ins3kb mutations of the SLC25A13 gene. Treatment with sodium benzoate and L-arginine was attempted. All clinical and abnormal laboratory findings were resolved by the age of 6 months. The boy is now 33 months old and developing normally with a preference for beef and ham (Figs. 1C and 2C).

Patient 4, a 5-month-old female, was admitted for the investigation of prolonged jaundice and hepatomegaly. The liver was palpable $4 \mathrm{~cm}$ below the right costal margin. Laboratory data showed an aspartate aminotransferase level of $89 \mathrm{IU} / 1$, an alanine aminotransferase of $35 \mathrm{IU} / 1$ (normal range 5-45 IU/1), a $\gamma$-glutamyl transferase of $218 \mathrm{IU} / 1$, a serum albumin of $2.2 \mathrm{~g} / \mathrm{dl}$ and a total/direct bilirubin level of $5.7 / 3.1 \mathrm{mg} / \mathrm{dl}$. Serum amino acid analysis revealed a methionine level of $49.8 \mu \mathrm{mol} / 1$, a threonine of $497.3 \mu \mathrm{mol} / 1$, a citrulline of $90.4 \mu \mathrm{mol} / 1$ and a lysine level of $247.3 \mu \mathrm{mol} / 1$ (normal range 52-196 $\mu \mathrm{mol} / \mathrm{l}$ ). An abdominal ultrasonogram revealed an enlarged and homogeneous liver with increased echogenicity. Liver histology obtained by needle biopsy showed diffuse microvesicular or macrovesicular fatty changes with periportal fibrosis. Mutation analysis of the SLC25A13 gene identified a known mutation of c.851_854del (c.851del4) and a novel mutation of c.1177G $>$ A (p.Gly393Ser). The girl improved with time; the jaundice and hepatomegaly becoming less problematic. She is now 8 months of age.
Clinical characteristics and genotypes of CTLN2. Patient 5, a previously healthy 24-year-old man, was brought to the hospital due to abdominal discomfort, vomiting and disorientation. He was semicomatose and his blood ammonia level was $537 \mu \mathrm{mol} / 1$. His mental status improved by fasting and with frequent lactulose enemas. The serum ammonia level fluctuated after he was placed on a protein-restricted diet. Serum citrulline $(286 \mu \mathrm{mol} / \mathrm{l})$ and lysine $(411 \mu \mathrm{mol} / \mathrm{l})$ levels were markedly elevated. Serum methionine $(53 \mu \mathrm{mol} / \mathrm{l})$, arginine $(134 \mu \mathrm{mol} / \mathrm{l})$, threonine $(190 \mu \mathrm{mol} / \mathrm{l})$, and serine (94 $\mu \mathrm{mol} / \mathrm{l})$ levels were within normal limits. The citrulline to serine ratio was 3.04 and the threonine to serine ratio was 2.02. No mutation was detected in the ASS gene but c. $1230+1 \mathrm{G}>\mathrm{A}$ (IVS13+1G $>$ A) and IVS16ins $3 \mathrm{~kb}$ mutations were identified by SLC25A13 gene analysis. The man has been doing well without symptoms of hyperammonemia and prefers protein-rich foods.

Patient 6, a man aged 37 years, developed recurrent attacks of altered consciousness and seizure. His first attack occurred after his divorce at 36 years of age, and the episode recurred five times a year. The episodes were particularly associated with alcohol ingestion. Laboratory findings revealed a high citrulline level $(282.8 \mu \mathrm{mol} / \mathrm{l})$, normal levels of methionine $(24.3 \mu \mathrm{mol} / 1)$, arginine $(106.4 \mu \mathrm{mol} / 1)$, threonine $(99.4 \mu \mathrm{mol} / \mathrm{l})$ and a low serine level $(59.5 \mu \mathrm{mol} / \mathrm{l}$; normal range $60-181 \mu \mathrm{mol} / \mathrm{l})$. The citrulline to serine ratio was 4.75 and the threonine to serine ratio was 1.67. A $\gamma$-glutamyl transferase level of $213 \mathrm{IU} / 1$ and an $\alpha$-fetoprotein level of $38.4 \mathrm{ng} / \mathrm{ml}$ (normal range $<10 \mathrm{ng} / \mathrm{ml}$ ) were measured. Hepatosplenomegaly was absent and a mild porto-periportal activity with fatty change was observed in a liver biopsy specimen. An electroencephalogram and brain magnetic resonance imaging showed normal findings. Mutation analysis of the SLC25A13 gene identified a compound 
Table I. Summary of citrin deficiency cases in Korea.

\begin{tabular}{|c|c|c|c|c|c|c|}
\hline $\begin{array}{l}\text { Case } \\
\text { no. }\end{array}$ & $\begin{array}{c}\text { Clinical } \\
\text { phenotype }\end{array}$ & $\begin{array}{c}\text { Age at } \\
\text { diagnosis/sex }\end{array}$ & Presenting symptoms & Biochemical findings & $\begin{array}{l}\text { Mutation of } \\
\text { SLC25A13 }\end{array}$ & Outcome \\
\hline 1 & NICCD & Newborn/M & Picked up by MS/MS & $\begin{array}{l}\text { Hyperammonemia, hypercitrullinemia, } \\
\text { galactosemia }\end{array}$ & $\begin{array}{l}\text { IVS } 11+1 \mathrm{G}>\mathrm{A} \\
\text { IVS16ins } 3 \mathrm{~kb}\end{array}$ & $\begin{array}{l}\text { Resolved by } \\
5 \text { months }\end{array}$ \\
\hline 2 & NICCD & Newborn/F & Picked up by MS/MS & $\begin{array}{l}\text { Hyperammonemia, hypercitrullinemia, } \\
\text { galactosemia, cholestasis, } \\
\text { hypoproteinemia }\end{array}$ & $\begin{array}{l}\text { IVS13+1G }>\text { A } \\
\text { IVS16ins } 3 k b\end{array}$ & $\begin{array}{l}\text { Resolved by } \\
9 \text { months }\end{array}$ \\
\hline 3 & NICCD & Newborn/M & Picked up by MS/MS & $\begin{array}{l}\text { Hyperammonemia, hypercitrullinemia, } \\
\text { galactosemia, cholestasis, } \\
\text { hypoproteinemia }\end{array}$ & $\begin{array}{l}\text { 851del4 } \\
\text { IVS16ins3kb }\end{array}$ & $\begin{array}{l}\text { Resolved by } \\
6 \text { months }\end{array}$ \\
\hline 4 & NICCD & 3 months/F & $\begin{array}{l}\text { Cholestatic jaundice, } \\
\text { gray-colored stool }\end{array}$ & Hyperammonemia, hypercitrullinemia & $\begin{array}{l}\text { 851del4 } \\
\text { G393S }\end{array}$ & $\begin{array}{l}\text { Resolved by } \\
5 \text { months }\end{array}$ \\
\hline 5 & $\begin{array}{c}\text { Adult } \\
\text { CTLN2 }\end{array}$ & 28 years/M & $\begin{array}{l}\text { Loss of consciousness, } \\
\text { vomiting, seizures }\end{array}$ & Hyperammonemia, hypercitrullinemia & $\begin{array}{l}\text { IVS13+1G }>\text { A } \\
\text { IVS16ins } 3 \mathrm{~kb}\end{array}$ & $\begin{array}{l}\text { Recovered } \\
\text { without } \\
\text { sequelae }\end{array}$ \\
\hline 6 & $\begin{array}{c}\text { Adult } \\
\text { CTLN2 }\end{array}$ & 37 years/M & $\begin{array}{l}\text { Altered consciousness, } \\
\text { lethargy }\end{array}$ & Hyperammonemia, hypercitrullinemia & $\begin{array}{l}\text { IVS } 11+1 \mathrm{G}>\mathrm{A} \\
\quad 851 \mathrm{del} 4\end{array}$ & $\begin{array}{l}\text { Recovered } \\
\text { without } \\
\text { sequelae }\end{array}$ \\
\hline
\end{tabular}

MS/MS, mass spectrometry/mass screening.

heterozygote of c. $1177+1 \mathrm{G}>\mathrm{A}$ (IVS $11+1 \mathrm{G}>\mathrm{A})$ and c.851_854del (c.851del4). The man recovered without neurological sequellae and had a special fondness for a protein-rich diet such as eel and meat.

The six cases of citrin deficiency in Korea are summarized in Table I.

\section{Discussion}

CTLN2 is caused by a defect in the SLC25A13 gene; the wildtype gene encodes citrin, a calcium-binding mitochondrial AGC (1). After the discovery of the SLC25A13 gene, the disease spectrum has been explored. Mutations in the SLC25A13 gene have been found in neonates suffering from cholestasis and multiple aminoacidemia, involving elevated levels of citrulline, threonine, methionine and tyrosine $(2,10)$. This disease has been designated as NICCD. Liver function tests in NICCD patients show various degrees of hepatocyte damage. Liver biopsies from NICCD patients show fatty change, round cell infiltration, and mild fibrosis; all of these findings are consistent with the pathology of CTLN2. The clinical phenotypes of NICCD are diverse, ranging from asymptomatic elevation of citrulline levels to severe tyrosinemia-like features. Biochemical findings of NICCD include significantly high levels of galactose, bile acids, $\gamma$-glutamyl transferase and alkaline phosphatase. Hypoproteinemia and mildly elevated aminotransferase levels have also been detected (8). The symptoms of NICCD are resolved by 12 months of age without special treatment. The diet should contain lactose-free milk, fat-soluble vitamins and medium-chain triglycerides. One patient with NICCD was reported, however, to develop progressive liver failure and subsequently underwent liver transplantation (11). After NICCD is resolved, patients seem healthy. Information on the natural history of the disease during this adaptation period is, however, scanty. Much later in life, some of these NICCD patients may develop CTLN2 $(12,13)$. Thus, some type of adaptation or compensation improves the symptoms in childhood and adolescence (14).

A characteristic feature of CTLN2 is the late onset of serious and recurrent neurological symptoms such as sudden disturbances of consciousness and abnormal behaviors, when patients are aged 20-50 years. The hepatic ASS enzyme activity is reduced, although there is no mutations of the ASS gene. Hyperammonemia in CTLN2 patients causes brain edema and may be fatal. Hepatocellular carcinoma without cirrhosis, hyperlipidemia and pancreatitis have also been reported in CTLN2 patients (15-17).

In this study, 3 out of the 4 NICCD patients were detected incidentally by neonatal tandem mass screening. No subjective symptoms were present, and one NICCD patient had cholestatic jaundice. All two CTLN2 patients complained of an abrupt or recurrent onset of neurological symptoms. Most patients with citrin deficiency had peculiar dietary habits, with a preference for protein- and fat-rich food, such as ham, beef and soy, and a dislike for high carbohydrate diets. A similar observation has been made of Japanese patients (14).

Citrin is an AGC, encoded by the SLC25A13 gene on chromosome 7q21.3, and consists of 18 exons and 675 amino acid residues. The gene spans $200 \mathrm{~kb}$. The enzyme is relatively liver-specific. AGC plays a role in urea metabolism, protein and nucleotide synthesis, and gluconeogenesis from lactate 
(16). Since the identification of the SLC25A13 gene in CTLN2 patients, 13 common mutations have been described in Japanese patients: [I]:851de14, [II]:IVS $11+1 \mathrm{G}>\mathrm{A}$, [III]:1638ins23, [IV]:S225X, [V]:IVS13+1G >A, [VI]:1800ins1, [VII]:R605X, [VIII]:E601X, [IX]:E601K, [X]:IVS6+5G>A, $[\mathrm{XI}]: \mathrm{R} 184 \mathrm{X},[\mathrm{XIV}]: \mathrm{IVS} 6+1 \mathrm{G}>\mathrm{C}$, and [XX]:Ex16+74_IVS1732 del516 (1,3,18-20). Other rare mutations, [XV]:Ex15dup (IVS14_15) and [XXI]:L598R, have been detected in various ethnic groups $(4,21)$. Four mutations, [I], [II], [V] and [XIX]:IVS16ins $3 \mathrm{~kb}$, found in this study have been already found in Japanese patients $(1,8)$ and a novel mutation (p.G393S) was identified in patient 4.

Frequency analysis of 12 mutant SLC25A13 alleles of overseas residents in Japan, using DNA samples from healthy controls and neonatal mass screening filter papers, showed mutant allele frequencies of 1/112 in Korean, 1/69 in Japanese, 1/940 in northern Chinese, 1/48 in southern Chinese of the Yangtze River, and 1/57 in Taiwanese subjects $(5,20)$. These results suggest that the incidence of citrin deficiency is $1 / 50,000$ in Korea and $1 / 19,000$ in Japan. However, only eight subjects have been diagnosed by molecular genetic analysis in Korea to date. These data indicate that the disease is being under-diagnosed in Korea, in part because physicians are not familiar with the condition. Three of our four NICCD patients were initially suspected to have citrullinemia from data provided by a newborn screening test using tandem mass spectrometry. Only a few patients can be diagnosed by a newborn screening test because not all NICCD patients show highly elevated plasma citrulline levels.

Several studies have sought to develop methods for early diagnosis and neonatal screening of NICCD. Because most mutations in the SLC25A13 gene are nonsense mutations, frameshift mutations or cause aberrant splicing, large SLC25A13 proteins are not produced and most gene products are cross-reacting immunological material (CRIM)negative (18). Therefore, screening could be performed by Western blotting using an anti-citrin antibody (22). Another method is tandem mass screening, where high citrulline levels $(>30 \mu \mathrm{mol} / \mathrm{l})$, and a high ratio of citrulline to serine $(>0.34)$ and threonine to serine $(>1.19)$ are identified (23). Additional findings such as high methionine, arginine, phenylalanine and galactose levels support the diagnosis and enhance the positive predicted value of the test (24). To accurately measure the incidence of citrin deficiency in the Korean population, large-scale population-based studies and additional tests for searching for rare or novel mutations are needed.

Many issues in NICCD patient management require attention. Dietary protein restriction is not usually recommended. Rather, adequate protein intake and arginine supplementation should be encouraged, except in the case of symptomatic hyperammonemia. Carbohydrate intake must be restricted, because NICCD is considered a form of carbohydrate poisoning (25). A diet high in carbohydrates and low in protein raises NADH levels in the cytoplasm through glycolysis and consumption of lactic acid. The process of NADH reoxidation is impaired in citrin-deficient patients. It is well-known that these patients detest sweet foods such as rice or fruit, and prefer meat, egg or soy. An encouraging report, describing the therapeutic benefit of sodium pyruvate in citrin-deficient mice, has been published (26). Various clinical treatment modalities remain valid, because the natural course of this disease is not fully understood.

All NICCD and CTLN2 patients discussed in this report were on low protein diets with arginine supplementation. In addition, hemodialysis was performed in two adult CTLN2 patients because of hyperammonemic encephalopathy.

In conclusion, the NICCD/CTLN2 disease incidence, the associated genotypes, the natural history, and the response to treatment, all remain poorly understood in Korean patients with citrin deficiency.

\section{Acknowledgements}

We express our gratitude to the patients and their family members for their participation in this study. This study was supported by grant no. 01-PJ10-PG6-01GN15-0001 from the Korean Ministry of Health and Welfare. This study was also supported in part by Grant-in-Aids for Scientific Research (B) and the Asia-Africa Science Platform Program from the Japan Society for the Promotion of Science, and by a Grant for Child Health and Development (17-2) from the Ministry of Health, Labor and Welfare in Japan.

\section{References}

1. Kobayashi K, Sinasac DS, Iijima M, et al: The gene mutated in adult-onset type II citrullinaemia encodes a putative mitochondrial carrier protein. Nat Genet 22: 159-163, 1999.

2. Ohura T, Kobayashi K, Tazawa Y, et al: Neonatal presentation of adult-onset type II citrullinemia. Hum Genet 108: 87-90, 2001 .

3. Yamaguchi N, Kobayashi K, Yasuda T, et al: Screening of SLC25A13 mutations in early and late onset patients with citrin deficiency and in the Japanese population: Identification of two novel mutations and establishment of multiple DNA diagnosis methods for nine mutations. Hum Mutat 19: 122-130, 2002.

4. Ben-Shalom E, Kobayashi K, Shaag A, et al: Infantile citrullinemia caused by citrin deficiency with increased dibasic amino acids. Mol Genet Metab 77: 202-208, 2002.

5. Kobayashi K, Lu YB, Li MX, et al: Screening of nine SLC25A13 mutations: their frequency in patients with citrin deficiency and high carrier rates in Asian populations. Mol Genet Metab 80: 356-359, 2003.

6. Hwu WL, Kobayashi K, Hu YH, et al: A Chinese adult onset type II citrullinaemia patient with 851 del4/1638ins 23 mutations in the SLC25A13 gene. J Med Genet 38: E23, 2001.

7. Saheki T and Kobayashi K: Mitochondrial aspartate glutamate carrier (citrin) deficiency as the cause of adult-onset type II citrullinemia (CTLN2) and idiopathic neonatal hepatitis (NICCD). J Hum Genet 47: 333-341, 2002.

8. Tazawa Y, Kobayashi K, Abukawa D, et al: Clinical heterogeneity of neonatal intrahepatic cholestasis caused by citrin deficiency: case reports from 16 patients. Mol Genet Metab 83: 213-219, 2004.

9. Kim SZ, Jeon YM, Song WJ, Ushikai M, Saheki T and Kobayashi K: Two cases of citrin deficiency detected by newborn screening in Korea. J Inherit Metab Dis 29 (suppl 1): 84, 2006

10. Tazawa Y, Kobayashi K, Ohura T, et al: Infantile cholestatic jaundice associated with adult-onset type II citrullinemia. J Pediatr 138: 735-740, 2001.

11. Tamamori A, Okano Y, Ozaki H, et al: Neonatal intrahepatic cholestasis caused by citrin deficiency: severe hepatic dysfunction in an infant requiring liver transplantation. Eur J Pediatr 161: 609-613, 2002.

12. Kasahara M, Ohwada S, Takeichi T, et al: Living-related liver transplantation for type II citrullinemia using a graft from heterozygote donor. Transplantation 71: 157-159, 2001.

13. Tomomasa T, Kobayashi K, Kaneko H, et al: Possible clinical and histologic manifestations of adult-onset type II citrullinemia in early infancy. J Pediatr 138: 741, 2001. 
14. Saheki T, Kobayashi K, Iijima M, et al: Pathogenesis and pathophysiology of citrin (a mitochondrial aspartate glutamate carrier) deficiency. Metab Brain Dis 17: 335-346, 2002.

15. Hagiwara N, Sekijima Y, Takei Y, et al: Hepatocellular carcinoma in a case of adult-onset type II citrullinemia. Intern Med 42: 978-982, 2003.

16. Saheki T, Kobayashi K, Iijima M, et al: Metabolic derangements in deficiency of citrin, a liver-type mitochondrial aspartateglutamate carrier. Hepatol Res 33: 181-184, 2005.

17. Ikeda S, Kawa S, Takei Y, et al: Chronic pancreatitis associated with adult-onset type II citrullinemia: clinical and pathologic findings. Ann Intern Med 141: W109-W110, 2004.

18. Yasuda T, Yamaguchi N, Kobayashi K, et al: Identification of two novel mutations in the SLC25A13 gene and detection of seven mutations in 102 patients with adult-onset type II citrullinemia. Hum Genet 107: 537-545, 2000.

19. Takaya J, Kobayashi K, Ohashi A, et al: Variant clinical courses of 2 patients with neonatal intrahepatic cholestasis who have a novel mutation of SLC25A13. Metabolism 54: 1615-1619, 2005.

20. Lu YB, Kobayashi K, Ushikai M, et al: Frequency and distribution in East Asia of 12 mutations identified in the SLC25A13 gene of Japanese patients with citrin deficiency. J Hum Genet 50: 338-346, 2005.
21. Luder AS, Tabata A, Iijima M, Kobayashi K and Mandel H: Citrullinemia type 2 outside East Asia: Israeli experience. J Inherit Metab Dis 29 (suppl 1): 59, 2006.

22. Tokuhara D, Iijima M, Tamamori A, et al: Novel diagnostic approach to citrin deficiency: Analysis of citrin protein in lymphocytes. Mol Genet Metab 90: 30, 2007.

23. Kobayashi K and Saheki T: Gene Reviews: Citrin deficiency. University of Washington, Seattle, 2005.

24. Tamamori A, Fujimoto A, Okano Y, et al: Effects of citrin deficiency in the perinatal period: feasibility of newborn mass screening for citrin deficiency. Pediatr Res 56: 608-614, 2004.

25. Imamura Y, Kobayashi K, Shibatou T, et al: Effectiveness of carbohydrate-restricted diet and arginine granule therapy for adult-onset type II citrullinemia: a case report of siblings showing homozygous SLC25A13 mutation with and without the disease. Hepatol Res 26: 68-72, 2003.

26. Moriyama M, Li MX, Kobayashi K, et al: Pyruvate ameliorates the defect in ureogenesis from ammonia in citrin-deficient mice. J Hepatol 44: 930, 2006. 